\title{
Besides Purkinje cells and granule neurons: an appraisal of the cell biology of the interneurons of the cerebellar cortex
}

\author{
Karl Schilling • John Oberdick • Ferdinando Rossi • \\ Stephan L. Baader
}

Accepted: 15 July 2008 / Published online: 2 August 2008

(C) The Author(s) 2008

\begin{abstract}
Ever since the groundbreaking work of Ramon y Cajal, the cerebellar cortex has been recognized as one of the most regularly structured and wired parts of the brain formed by a rather limited set of distinct cells. Its rather protracted course of development, which persists well into postnatal life, the availability of multiple natural mutants, and, more recently, the availability of distinct molecular genetic tools to identify and manipulate discrete cell types have suggested the cerebellar cortex as an excellent model to understand the formation and working of the central nervous system. However, the formulation of a unifying model of cerebellar function has so far proven to be a most cantankerous problem, not least because our understanding of the internal cerebellar cortical circuitry is clearly spotty. Recent research has highlighted the fact that cerebellar cortical interneurons are a quite more diverse and heterogeneous class of cells than generally appreciated, and have provided novel insights into the mechanisms that underpin the development and histogenetic integration of these cells. Here, we provide a short overview of cerebellar cortical interneuron
\end{abstract}

K. Schilling $(\bowtie) \cdot$ S. L. Baader

Anatomisches Institut, Anatomie und Zellbiologie,

Rheinische Friedrich-Wilhelms-Universität,

Nussalle 10, 53115 Bonn, Germany

e-mail: karl.schilling@uni-bonn.de

J. Oberdick

Department of Neuroscience,

Center for Molecular Neurobiology and Department

of Neuroscience, The Ohio State University, Columbus, OH, USA

F. Rossi

Department of Neuroscience,

"Rita Levi Montalcini Centre for Brain Repair",

National Institute of Neuroscience,

University of Turin, Torino, Italy diversity, and we summarize some recent results that are hoped to provide a primer on current understanding of cerebellar biology.

Keywords Interneuron - Basket cell · Stellate cell · Lugaro cell · Unipolar brush cell · Candelabrum cell . Development

\section{Introduction}

"The cerebellar cortex is built from four main types of neurons: granule cells, Purkinje cells and two types of inhibitory interneurons, Golgi cells and the stellate/basket cells" (Voogd and Glickstein 1998): To this day, this statement, or any conceivable permutation or paraphrase of it, is a cornerstone of most descriptions introducing the basic anatomy of the cerebellum. Yet it is well-known that besides the four neuronal phenotypes just mentioned, the cerebellar cortex contains several other types of neurons, among them candelabrum cells, Lugaro cells, and unipolar brush cells. The fact that these latter cells are usually not mentioned in the standard introductory phrase to cerebellar histology (but see Rong et al. 2004 for a rare exception), or even standard textbooks, reflects nothing less than the fact that our knowledge of the existence of these cells, not to mention their function, is of relatively recent vintage, and often rather fragmentary.

Even among the better known constituents of cerebellar cortical circuitry, basket/stellate and Golgi cells may be set apart from Purkinje and granule cells by the fact that their developmental history, in particular, is only beginning to emerge. The availability of a number of natural and engineered mutants affecting primarily and/or directly Purkinje and/or granule cells have been known for quite some time 
(for reviews and further references, see, e.g., Caviness and Rakic 1976; Goldowitz and Hamre 1998; Oberdick et al. 1998; Sotelo 2004) and provided an inroad to unravel basic aspects of the differentiation, function and systemic significance of these cells. In contrast, genetic and molecular means to identify, characterize, or manipulate basket, stellate and Golgi cells, candelabrum neurons, Lugaro cells or unipolar brush cells have been largely elusive. It is not surprising, then, that these cells are typically not considered even in recent integrative views of cerebellar function (e.g., Apps and Garwicz 2005; Porrill et al. 2004; Boyden et al. 2004); at best, the more prominent Lugaro cells and unipolar brush cells are mentioned, and rather in passing (e.g., Ito 2008; Millen and Gleeson 2008).

Yet recently, a combination of classical morphological and molecular approaches has provided novel means to unravel the biology of these cells. Together, they constitute an important step in our understanding of the cellular makeup of the cerebellum and towards a systems-level understanding of how the functions of the cerebellar cortex are mechanistically implemented. Here, we try to summarize some of the more recent advances in our knowledge of the developmental history (Fig. 1), molecular makeup, and

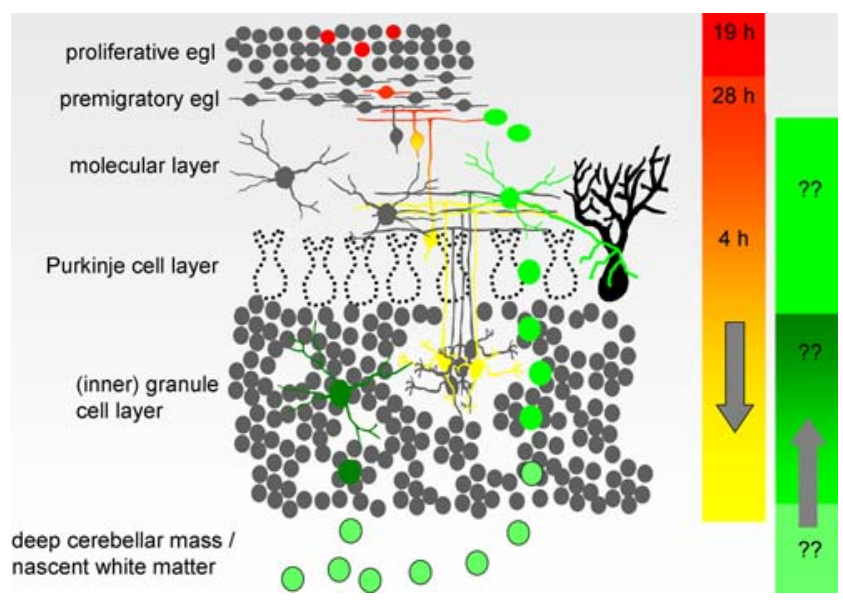

Fig. 1 A schematic view of histogenetic events in the early postnatal (in the mouse, say, up to postnatal day 15) cerebellar cortex. Granule cell precursors proliferate in the proliferative part of the external granule cell layer (egl). The actual cell cycle duration varies with age, but is in the range from 15 to $29 \mathrm{~h}$. After their last mitosis, granule cells remain in the inner part of the egl, where they start to elaborate neurites, for about $28 \mathrm{~h}$, before they rapidly (within some $4 \mathrm{~h}$ ) migrate to their final position in the inner granule cell layer and start to elaborate dendrites. Granule cell development is shown in red/yellow. In contrast, precursors of inhibitory interneurons (labeled greenish) reach the cerebellar cortex through the nascent white matter. They seem to freely traverse the nascent (internal) granule cell layer, but do not penetrate into the external granule cell layer. In contrast to our detailed knowledge of the kinetics and dynamics of granule cell formation and migration, hardly and details of the time course of the differentiation of inhibitory interneurons are known. For further details and additional references, see Fujita (1967); Sotelo (2004); Gliem et al. (2006); Weisheit et al. (2006) synaptic wiring (Fig. 2) of these less well-known constituents of the cerebellar cortex.

\section{Unipolar brush cells}

Of all cerebellar cortical interneurons, unipolar brush cells located in the granule cell layer stand out as the only excitatory neurons. While they have been described only rather recently, their cell and developmental biology is by now rather well defined. In 1977, Altman and Bayer first described a cerebellar neuron, located in the granule cell layer and preferentially found in the nodulus, which differed from granule or Golgi cells by its pale nucleus and its date of generation (Altman and Bayer 1977). By all known criteria, the cells then described seem to correspond to a subset of what is now known as unipolar brush cells. This descriptive name was coined by Mugnaini and associates, who also provided the first detailed description of these cells (Harris et al. 1993; Mugnaini and Floris 1994).

By combining the observations of Altman and Beyer (1977); cf also Fig. 22-23 and 22-24 in Altman and Bayer 1997) and Sekerkova et al. (2004), one may estimate that, within the vermis some $42 \%$ of all UBCs are localized in the flocculus (vermis of lobule X), and some $24 \%$ in the uvula (vermal part of lobule IX); the rest is distributed throughout other parts of the cerebellum. Further, these studies suggest that within the nodulus, the ratio of UBCs to Pjs is about 3:1, and in the declive (vermis of lobus VI) 0.3:1.

Unipolar brush cells are rather small neurons with a single, quite thick but stubby dendrite which terminates in a brush-like spray of dendrioles. Consequently, they appear as electronically compact neurons. UBCs are innervated by a single mossy fiber (MF), providing vestibular afferents, which makes contact with the entire dendritic brush and forms an unusually large synapse comprising multiple presynaptic release sites apposed to continuous regions of postsynaptic densities (Mugnaini et al. 1994; Rossi et al. 1995). This synapse is endowed with ionotropic, but lacks metabotropic glutamate receptors (Jaarsma et al. 1995). The latter, however (mGluR1, mGluR1alpha and mGluR2/ 3 immunoreactivity) are found in extrasynaptic membranes and densely localized to non-synaptic appendages of the UBC dendrioles (Mugnaini et al. 1997 and references cited therein). (Vestibulocerebellar) UBCs are also innervated by Golgi cells, which co-release GABA and glycine at these synapses. The UBC response, however, was found to be either mixed GABAergic and glycinergic, or purely glycinergic (Dugue et al. 2005). It is currently not known whether differences in $\mathrm{GABA}_{\mathrm{A}}$-receptor mediated responsiveness of UBCs reflect functional heterogeneity, or are due to differential maturation/differentiation of UBCs at postnatal days 


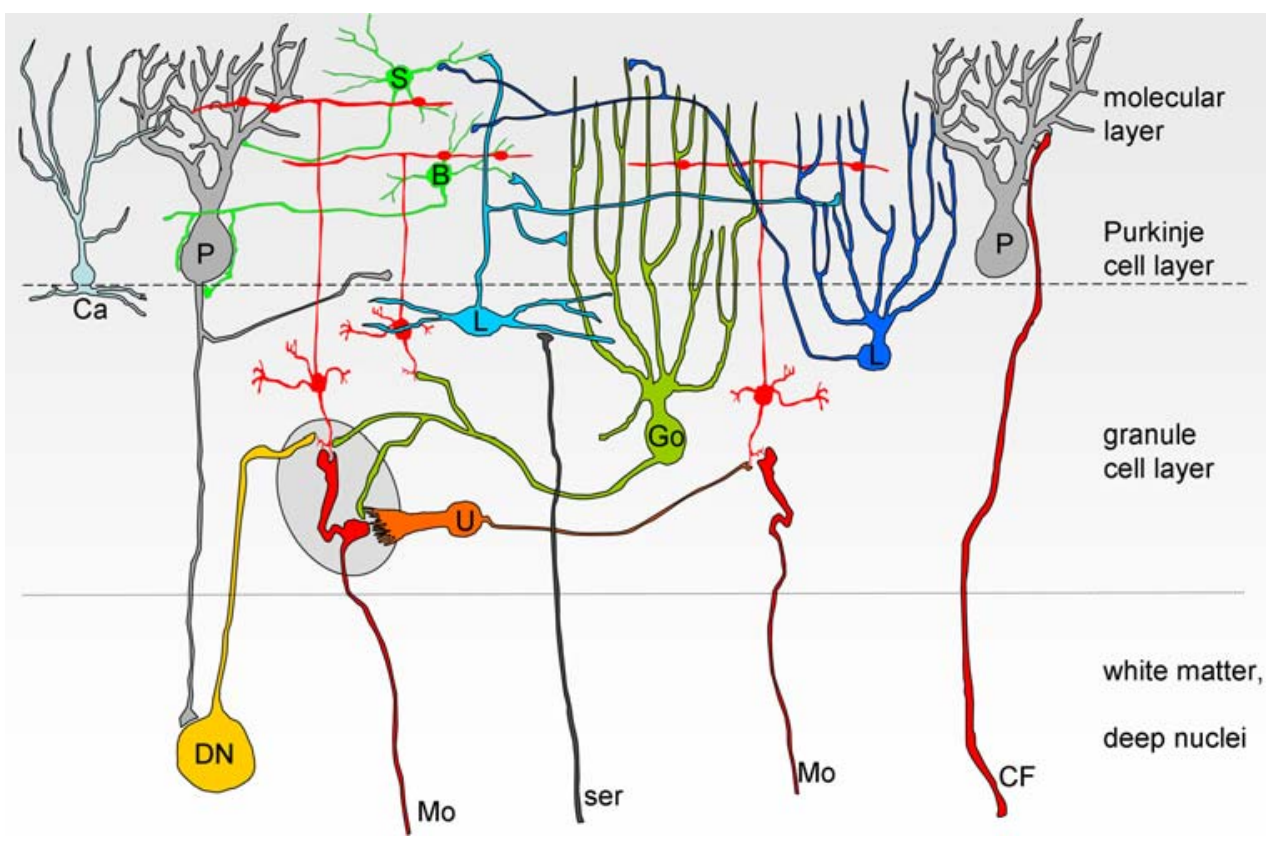

Fig. 2 A schematic and simplified view of the neurons of the cerebellar cortex and their wiring. For simplicity, neurochemically defined subsets of Golgi cells are shown as one single cell type (Go). Inhibitory Golgi $(G)$, basket $(B)$, stellate $(S)$ are shown in green; inhibitory Lugaro cells $(L)$ are shown in light (classical Lugaro cells) or dark blue (globular tye). Excitatory granule cells are labeled red, and excitatory unipolar brush cells $(U)$ are marked orange. Climbing $(C F)$ and mossy

17-21, when these recordings were acquired (from rat material). Finally, expression of PX2 purinergic receptors has also been observed in developing UBCs (Xiang and Burnstock 2005). While a dedicated source of ATP-ligand is currently unknown, this may form a basis of glia mediated modulation of these cells, somewhat analogous to the situation described for Purkinje (Brockhaus et al. 2004) or Lugaro cells (cf above; Saitow et al. 2005).

From the perikaryon, UBCs emanate a single axon, which takes a tortuous course within the granule cell layer and occasionally may course for a short distance through the white matter. Eventually, it branches repeatedly in the granule cell layer and forms a plexus displaying rosette-like excrescences that form the central component of glomeruli. In the latter, UBC axons are surrounded by granule cell dendrites and putative Golgi cell dendrites. Structurally, the synapses in these rosettes appear asymmetric (Berthie and Axelrad 1994; Rossi et al. 1995). Unipolar brush cells are glutamatergic (Nunzi et al. 2001), and given their wiring, they may contribute to a patterned spread of vestibular afferent excitation within the granule cell layer that has been considered to be equivalent to a feed-forward excitation (Dino et al. 2000). Their primary function seems to be to coordinate the synchronized activity of sets of granule cells, which in turn would regulate activity in spatially restricted subsets of Purkinje cells (cf Nunzi et al. 2001 for further details). fibers $(\mathrm{Mo})$ are also excitatory. The transmitter and wiring of candelabrum cells $(\mathrm{Ca})$ is not yet known, though their axons project into the molecular layer. $P$ Purkinje cells, ser serotoninergic afferents while this scheme shows how individual cell types are interconnected, it does not convey details of the three-dimensional details of these interconnections, which is brought about by the often virtually two-dimensional expanse of the dendrites and/or axons of individual cell types

Among the molecularly distinguishing features of unipolar brush cells are the relative abundance of (partially nonphosphorylated), high molecular weight neurofilament (NF-H), which presumably also forms the epitope recognized by monoclonal antibody Rat-302 (Harris et al. 1993). Attempts to define UBCs molecularly have also shown that there exist several partly overlapping subsets of UBCs, as defined by their differential expression of a panel of markers, including calretinin, the metabotropic glutamate receptor subunit $1 \alpha(\mathrm{mGluR} 1 \alpha)$, ionotropic glutamate receptor subunits 2 and/or 3 (GluR2, Glur2/3), glutamate transporters Vglut1 and Vglut2, secretogranin and chromogranin A (Jaarsma et al. 1995; Floris et al. 1994; Nunzi et al. 2002; Nunzi et al. 2003; cf also Vig et al. 2005b and references therein). Yet none of these markers is specific; moreover, there seems to exist pronounced species differences with respect to the expanse of UBC-subpopulations expressing these markers or combinations thereof. The physiologic consequences of this diversity are not understood.

Distinct subsets of UBCs may also be defined based on when these cells go through their last mitosis (their "birthdate"). In the rat, this occurs from embryonic day 15 (i.e., starting at about the time the last Purkinje cells are generated) and into the early postnatal period, up to about postnatal day 2 . Those that will eventually co-express calretinin and the ionotropic glutamate receptor subunit 2 (GluR2) go 
through their last mitosis, in between E15 and E21, with a pronounced peak at E17/18. Calretinin-negative cells, which seem to be identical to the pale cells of Altman and Bayer (1977), do so from E17 to E22, and into the first two postnatal days, with a broad peak from E19 to E21 (Sekerkova et al. 2004; Altman and Bayer 1977). Finally, as shown in mice, UBC subsets defined by differential staining for calretinin and $\mathrm{mGluR} 1 \alpha$ receive different sets of mossy fiber afferents, and this may indeed direct their actual neurochemical differentiation (Nunzi et al. 2002).

The recent observation that UBCs and their precursors express the transcription factor Tbr2 allowed for the first time to locate and follow these cells in the cerebellar anlage (Englund et al. 2006). These studies showed that precursors of UBCs can be localized to the rhombic lip in the early ( $\mathrm{E}$ 13.5 in the mouse) cerebellar anlage, from where they translocate into the cerebellar granule cell layer (cortex) via the nascent cerebellar white matter. Thus, these studies vindicate the observations of (Takacs et al. 2000) who had reported the presence of UBCs in the white matter of immature cerebellum. One caveat to heed is that we do not know whether all UBC-precursors are indeed Tbr2-positive.

While the work of Englund et al. (2006) clearly documents that the numerical expansion of the Tbr2-positive population is critically dependent on Math1 expression, it is less obvious whether this reflects a cell-intrinsic dependency, or rather an early regulatory interaction between the Math1-positive granule cell lineage and that of UBCs. Thus, while the authors report weak expression of B-galactosidase from the Math1 locus in Tbr2 positive cells, it remains open whether this is indeed indicative of expression of cognate Math1 in these cells, which would also be suggestive of a molecular relationship between these lineages. Indeed, data reported by Zervas et al. (2004) may suggest that precursors of UBCs may be distinguished from the granule cell lineage as early as E10.5 based on differential expression of wnt-1. These authors describe, in mice in which wnt-1 expressing cells were genetically marked at E10.5, descendants of these cells that, within the cerebellum, localized exclusively into the granule cell layer of lobules IX and X. While the data shown do not really allow these cells to be identified, their distribution is highly suggestive of unipolar brush cells, and clearly raises the issue as to the existence of an independent lineage as early as E10.5 in the mouse. This interpretation would also be consistent with the conclusion reached by Englund et al. (2006) that UBCs originate from the rhombic lip, as wnt-1 expression within the cerebellar anlage is restricted to this structure at E 10.5 (i.e. at the time the putative UBCs described by Zervas et al. were genetically marked; Li et al. 2002).

While it is clear that UBCs migrate through the nascent white matter, the mechanisms that direct their migration and assure their preferential localization in the vestibulocerebellum are not known. While UBC positioning is disturbed in reeler mice (Ilijic et al. 2005), it is not decided whether this is a direct effect or rather a reflection of the general disorganization of the cerebellar cortex in these mutants (Ilijic et al. 2005; Englund et al. 2006).

Following their last mitosis, UBCs acquire their characteristic and name-giving morphology over a rather protracted period, during which they also become synaptically invested. This has been described in detail for the rat by Morin et al. (2001) and for cat by Takacs et al. (2000). Is the normal differentiation of UBCs related to their synaptic integration? In reeler mice, a striking segregation between the localization of (calretinin-positive) UBCs, which are found displaced in the ventroposterior part of the cerebellum, and the terminal fields of secondary vestibulocerebellar afferents is observed (Vig et al. 2005a). Yet these findings are hard to interpret with respect to the interdependence of UBC positioning and afferent innervation, for two reasons: as pointed out by Vig et al. (2005a), the UBCs they identified could still be innervated by primary vestibulocerebellar afferents; and, calretinin-negative UBCs (which form the majority of all UBCs in the rat; mouse data not available) were not investigated. Indeed, Ilijic et al. (2005) have reported that UBCs in reeler mice form synaptic junctions with complex axon terminals, possibly representing mossy fibers and UBC axons, just like UBCs in wildtype animals. If there was any difference between ectopic UBCs in reeler and their normally situated counterparts in non-mutant animals, these seemed to be limited to a somewhat looser brush-structure of their terminal dendrites (Ilijic et al. 2005). In primary cerebellar cultures, which lack extracerebellar mossy fibers, UBCs develop and may be recognized based on their expression of calretinin. While some cultured UBCs develop the name-giving morphology of these cells, that of most cells is sufficiently variable to argue in favour of a strong influence of orderly local cues for the proper morphogenesis of these cells (Anelli et al. 2000; Anelli and Mugnaini 2001). We do not know whether and how afferent innervation impinges on the neurochemical differentiation and diversification of UBCs mentioned above.

\section{Candelabrum cells}

The candelabrum cell was first described in 1994 by Laine and Axelrad (1994) in the rat, and is the most recently delineated distinct neuronal phenotype of the cerebellar cortex. Candelabrum cell perikarya are located within the ganglionic (Purkinje) cell layer, and they are usually elongated along the vertical axis. Typically, these cells have one or two long, rarely branched dendrites, which ascend almost vertically into the molecular layer, and several (3-5) 
short dendrites which project into the granule cell layer, where they run preferentially in the horizontal plane (Fig. 2). Both types of dendrites are covered with spines. The candelabrum cell axon projects into the molecular layer, where it runs horizontally and emits multiple beaded branches, which ascend vertically through most of the molecular layer, where they are preferentially arranged in parasagittal planes. This axonal plexus may either occupy a territory that essentially overlaps with the area occupied by the same cell's ascending dendrites, or be displaced laterally some variable distance. Candelabrum cells are distributed throughout all parts of the cerebellar cortex at apparently roughly equal density.

While the dendritic structure of candelabrum cells suggest that parallel fibers, ascending granule cell axons, but also basket/stellate cells and climbing fibers may provide afferent input to them, their afferents have so far not been identified. The same holds for its target(s), although the axonal structure makes Purkinje cell dendrites (and those of basket/stellate cells) likely targets. While their location and details of their dendritic and axonal morphology certainly distinguishes candelabrum cells from basket and stellate cells, their presumed wiring also suggests that they may be part of an extended basket/stellate/candelabrum cell classification. This might suggest a transmitter phenotype and also hint at their potential developmental history. Indeed, candelabrum cells in the monkey (Macaca) cerebellum have recently been shown to be immunoreactive for glycine, GABA, and GAD (the GABA-synthesizing enzyme glutamate decarboxylase; Crook et al. 2006), an observation in accord with the previous tentative identification, in rats, of cells doubly reactive for GAD67 and the glycine transporter, Glyt2, as possibly comprising candelabrum cells (Tanaka and Ezure 2004). In human cerebellum, a cell-type which based on its location and the shape of its perikaryon may be classified as candelabrum cells were found to be GAD65/67 (the antibody used did not allow to distinguish isoforms; Flace et al. 2004). Thus, current evidence concurs to indicate that candelabrum cells use GABA and glycine as transmitters.

The work of Crook et al. (2006) also indicates that candelabrum are rather sparsely contacted by GAD-immunopositive presynaptic elements. However, we are essentially ignorant as to the synaptic investment of candelabrum cells, their afferents, their receptor endowment, let alone their electrophysiological properties.

To date, we know of no reliable and specific molecular marker for candelabrum cells. We have no numerical estimates as to their prevalence. Their developmental history is completely obscure. Thus, we do not know whether Candelabrum cells, or their precursors, are positive for ROR $\alpha$ and/or Pax-2; clarification of these points, should help to clarify whether and how Candelabrum cells relate to Golgi, basket and stellate cells (see also below).
Large inhibitory interneurons of the granule cell layer

Often, large inhibitory interneurons in the granule cell layer have been equated with Golgi neurons; yet it was Camillo Golgi (1903) himself who first drew attention to a class of cells distinct from those that later were to be called by his name, and which are now known as Lugaro cells. This name acknowledges the first detailed description of these cells by Ernesto Lugaro (1894). Moreover, and significantly, recent research has unveiled an rather unexpected molecular heterogeneity of Golgi neurons themselves (e.g., Geurts et al. 2003; Simat et al. 2007), that waits to be understood functionally.

Classic Lugaro cells have a fusiform cell body and are intermediate in size between granule cells and Golgi cells. Consequently, they are often referred to also as fusiform cells of Lugaro. They are found in all parts of the cerebellar cortex, where they are located at the border between the Purkinje cell layer and the upper part of the granule cell layer. Initial numerical estimates had put the Purkinje cell/ Lugaro cell ratio at about 15:1 in the rat (Dieudonne and Dumoulin 2000) and 30:1 in the cat (Sahin and Hockfield 1990). More recently, a detailed neurochemical analysis of large granule cell layer interneurons indicated that in the mouse, Lugaro cells account for about $1 / 3$ of all inhibitory granule cell layer interneurons, and thus are more numerous than initially estimated (Simat et al. 2007).

The longer axis of classical, fusiform cells of Lugaro is oriented in the parasagittal plane. Typically, it emanates two pairs of long, rarely dividing dendrites, which run just underneath the Purkinje cell layer, also in the parasagittal plane. However, as the two dendrites originating from one pole of the cell body also diverge from each other in the horizontal plane, the actual dendritic field covered by a typical Lugaro cell may be better perceived as an rectangle, located just underneath the Purkinje cell layer, with its long axis parallel to the sagittal plane. These dendrites are of rather variable length, measuring, in the rat, from some 100 to $700 \mu \mathrm{m}$ (Laine and Axelrad 1996). Lugaro cells are currently viewed as the primary target of serotoninergic input into the cerebellar cortex (Dieudonne and Dumoulin 2000). They are also innervated by recurrent Purkinje cell axon collaterals (Palay and Chan-Palay 1974), and basket cells (Fox et al. 1967). Finally, it has been observed that Lugaro cells are sensitive to ADP, as mediated through P2Y purinoreceptors, and that $\mathrm{P} 2 \mathrm{Y}$ receptor activation may modulate inhibitory input from Lugaro to Purkinje cells (see below) in a complex spatio-temporal pattern (Saitow et al. 2005). The most likely source of ATP/ADP seem to be cerebellar astrocytes, in particular Bergmann glia (Saitow et al. 2005).

While the actual course of Lugaro cell axons may be quite variable, their defining feature is that they all terminate 
within the molecular layer, although they also give off collaterals into the granule cell layer (Laine and Axelrad 1996). All Lugaro cells have been reported to have a local axonal projection into the molecular layer just above the originating cell perikaryon; in addition, some Lugaro cells also have projections that reach more distal targets, which, however, are again located in the molecular layer. On their way, these longer axons may even course through the white matter (Laine and Axelrad 1996). As direct targets of Lugaro cells, basket and stellate cells have been identified only by morphological means (Laine and Axelrad 1998), whereas the projections of Lugaro cells onto Golgi (Dieudonne and Dumoulin 2000; Dumoulin et al. 2001; Dieudonne 1995) and Purkinje cells (Dean et al. 2003) have been analyzed functionally. It has been estimated that one Lugaro cell projects to more than 100 Golgi cells (Dieudonne and Dumoulin 2000); comparable numerical estimates for the Lugaro to Purkinje cell, or Lugaro to basket/ stellate cell projections are not available.

Whereas the Lugaro cell input to Golgi cells has mixed GABAergic and glycinergic components (Dumoulin et al. 2001), their input to (juvenile; analyzed at postnatal day 14 in the rat) Purkinje cells is mediated only by $\mathrm{GABA}_{\mathrm{A}}$ receptors (Dean et al. 2003). (Adult) Purkinje cells do express glycine receptors (Triller et al. 1987), though these are rather sparsely localized on main dendritic shafts. It is presently not clear whether the failure to detect glycinergic input into Purkinje cells by Lugaro cells relates to the developmental expression of glycinergic receptors by Purkinje cells, or rather reflects differential loading of Lugaro cell vesicles targeted to Lugaro/Golgi and Lugaro/Purkinje cell synapses, respectively (for a model, cf Fremeau et al. 2004; Schuske and Jorgensen 2004). As the vesicular transporter VGAT/VIAAT is nonselective for GABA or glycine (which compete for it; Chaudhry et al. 1998; Wojcik et al. 2006), such a scenario would imply differential sorting and/ or membrane availability of membrane transporters for glycine and GABA. Indeed, there is a growing body of evidence that points to an intricate regulation of the sorting and membrane insertion of Glyt2, Gat-1, and Gat-2 (e.g., Muth et al. 1998; Martinez-Maza et al. 2001; Farhan et al. 2008; see also Chiu et al. 2002), which are expressed in large molecular layer interneurons of the cerebellum (cf the Allen Brain Atlas; Lein et al. 2007). Intriguingly, Gat-2 is subject to regulation by serotonin; as mentioned above, Lugaro cells are the primary target of serotoninergic projections to the cerebellar cortex (Dieudonne and Dumoulin 2000).

Besides classical, spindle-shaped Lugaro cells in the upper part of the granule cell layer, a second type of neuron is now grouped as Lugaro cells, primarily based on its typical wiring and axonal projection pattern (Fig. 2). These cells were recently described by Laine and Axelrad (2002).
They share with the classical Lugaro cells just described the typical projection of their axons; yet they occupy a deeper position within the granule cell layer, and they have a preferentially globular perikaryon. Also, the expanse and pattern of their dendritic processes are somewhat reminiscent of Golgi cells. In addition to their axonal projection, immunoreactivity for calretinin and their innervation by recurrent Purkinje cell axons provide convincing arguments to classify these cells indeed as Lugaro cells (Laine and Axelrad 2002). Apparently these cells are identical to "Golgi-like" calretinin-positive but mGluR2-negative cells described by Geurts et al. (2001), although the two reports differ as to whether these cells are preferentially found in the more superficial (Laine and Axelrad 2002)or deeper parts (Geurts et al. 2001) of the granule cell layer.

Of all cerebellar cortical neurons, Lugaro cells are the only ones stained by monoclonal antibody Cat-301 (Sahin and Hockfield 1990), although it is not clear whether all Lugaro cells are positive for this marker. Outside the cerebellar cortex, this antibody recognizes multiple types of neurons, and its antigen is subject to developmental and activity-dependent regulation (Lander et al. 1997). Molecularly, it has been identified as a distinctly glycosylated form of the extracellular matrix protein, aggrecan, which forms part of perineuronal nets (Lander et al. 1998; Matthews et al. 2002). Cat-301 is believed to have a role in the stabilization of synaptic structures, although no definitive role for this antigen has been identified.

There is some indication, though no definitive data, that Lugaro cells start to be born at embryonic day 14-15, in the rat (Sekerkova et al. 2004), and in all likelihood they arise (together with) other inhibitory interneurons of the cerebellar cortex, from the fourth ventricle neuroepithelium.

As a group, Golgi cells differ from Lugaro cells primarily by their axonal projection pattern: While Lugaro cells, including their globular variant, target all other inhibitory interneurons of the cerebellar cortex, Golgi cells project selectively to granule cells and UBCs, which they contact within mossy fiber glomeruli. As Golgi cells receive both mossy fiber and granule cell (parallel fiber) input, they are poised to realize both a feed-forward and a feed-back loop onto granule cells. It has been known since the days of Ramon y Cajal that Golgi cells show quite a degree of heterogeneity, and Cajal initially proposed the existence of four variants, based on axonal projection patterns (Ramon y Cajal 1899). Since then, various classification schemes have been proposed, of which the most recent one, by Simat et al. (2007), incorporates molecular data that holds the prospect for defining functional classifications. These authors provide evidence that allows the delineation of five types of Golgi cells, based on the variable expression of the GABA-synthetic enzyme, Gad67, the cell membrane transporter for glycine, GlyT2, of secretogranin, and of the 
metabotropic glutamate receptor mGluR2. About twothirds of all Golgi cells, referred to as type 1, are positive for Gad67, GlyT2 (and hence GABAergic and glycinergic), secretogranin, and also mGluR2. A second set (type 2), comprising less than $10 \%$ of all Golgi cells, shares the same basic neurochemical makeup but does not express neurogranin. Type 3 Golgi cells encompass actually two subsets, each comprising some $2-5 \%$ of all Golgi cells, that share expression of mGlutR2 and GlyT2, but differ as only one subset expresses Gad67. Type 4 cells are pure GABAergic cells that do not express GlyT2, and are also negative for mGluR2; they are, however, immunopositive for neurogranin. These type 4 cells comprise about $15 \%$ of all Golgi cells in mice. Finally, less than 5\% of all Golgi cells are of type 5, which does not express Gad67, nor mGluR2, nor neurogranin, but is positive for GlyT2. These neurochemical markers can also be utilized to tell apart Golgi cells from Lugaro cells, including their globular variant: Lugaro cells are all positive for both GlyT2 and GAD67, but negative for mGluR2,3 and neurogranin.

So far, these neurochemical differences have not been considered in any model trying to describe Golgi and/or Lugaro cell function, although the need to do so was clearly stressed already some 35 years ago (Mugnaini 1972). One caveat to be heeded in any attempt to integrate the exciting data of Simat et al. (2007) in such a scheme is that these authors relied on GFP expression from the Gad67 (Gad1) and Glyt2 locus. It has not been formally shown that these transgenes represent expression of cognate genes in all cell types analyzed, although available evidence leaves little doubt that this is indeed so. While coexpression of GABAergic and glycinergic traits has also been observed in rats (Tanaka and Ezure 2004) and primates (Ottersen et al. 1987), exact numerical data are missing, so that we cannot even speculate about possible species differences, and the evolutionary significance.

A critical issue when trying to assemble these recent data in a functional model is that we have no real idea whether the expression of genes used to define Golgi and also Lugaro cell subsets is indeed stable, or subject to dynamic, or plastic, regulation. This is particularly relevant in view of recent data that suggest that (terminal?) differentiation of cerebellar cortical inhibitory interneurons, including Golgi and Lugaro cells, but also basket and stellate neurons, is substantially driven by local cues impinging on pluripotent precursors of these cells (Leto et al. 2006) (see below).

\section{Inhibitory interneurons of the molecular layer: basket and stellate cells, or basket/stellate cells?}

As their names imply, basket and stellate cells were initially discerned based on the typical morphology of their axon (terminals), or their dendrites, respectively, and also by the position of their perikarya in the lower or upper molecular layer (Ramon y Cajal 1909). A systematic analysis of an admittedly small set of molecular layer neurons (but still the largest set that was systematically analyzed) indeed confirmed that the tendency to form a basket celltype of axon terminal in fact paralleled the position of the perikaryon within the molecular layer (Sultan and Bower 1998), as has oft been suggested based on observations in Golgi-stained material. Importantly, however, this study also suggested that molecular layer interneurons, if classified based on morphological criteria, constitute a single population that varies only gradually. Clearly, follow up on this notion must keep in mind the small experimental set available for this systematic analysis.

A molecular handle to address this issue was suggested by the observation that in mice null for cyclin D2, neurons from the upper molecular layer are conspicuously lacking. This has led to the suggestion that cyclin D2 is a key determinant of stellate cell formation, and indeed is required for the developmental "appearance of this sublineage" (Huard et al. 1999): This notion seems also supported by the observation that in the forebrain of cyclin D2-deficient mice, discrete subsets of interneurons are missing (Glickstein et al. 2007). However, this cannot be interpreted as an indication that cyclin D2 acts to "specify" a stellate cell-specific lineage. As pointed out (Huard et al. 1999; Glickstein et al. 2007), lack of cyclin D2 impedes proliferation, and it is well conceivable that this may lead to an exhaustion of the precursor cell pool from which cerebellar inhibitory interneurons originate before stellate cells-which are known to be born last-are indeed formed. Such an interpretation would be in keeping with the data that document that terminal differentiation, including the acquisition and expression of cell type specific traits for cerebellar inhibitory interneurons is driven by local cues. Intriguingly, cyclin D2 may play a more active role in this scenario than just supporting a sufficient number of cell cycles needed to generate a full complement of inhibitory cerebellar interneurons (see below). Other than cyclin D2, no molecular cues to differentiate basket from stellate cells have emerged so far.

\section{Development and differentiation of cerebellar (cortical) inhibitory interneurons}

While there is some controversy in the older literature as to the site of origin of cerebellar inhibitory interneurons, the historical consensus, or at least the prevailing view was that basket and stellate cells are derived from the external granule cell layer, and Golgi cells from the ventricular epithelium layer (see, e.g., Altman and Bayer 1997). Indirectly, this suggested the notion that the lineages of these cell 
types are well separated, in space, and presumably also in developmental potential. Although a series of earlier observations had put this view in question (prominent among them (Napieralski and Eisenman 1993; Hallonet and Le Douarin 1993) the view that all inhibitory cortical interneurons derive from a precursor population - and maybe even a common precursor-that reaches its final destinations by migrating through the deep cerebellar mass and nascent white matter gained broader attention and general acceptance following the reports by Zhang and Goldman (1996a, b) that inhibitory interneuronal precursors could be marked by injecting a retroviral marker into the deep parts of the cerebellar anlage. These studies also implied that precursors in this location (i.e., which had left the ventricular zone) were dividing, and they also raised the issue of a potential lineage relationship between inhibitory interneuronal precursors and other cells marked, notably glial cells (see also Mathis et al. 1997). A significant advance, and a methodological cornerstone for further research, was reached when Maricich and Herrup (1999) could define Pax2 as a marker for inhibitory interneuronal precursors. This allowed, for the first time, to localize these cells throughout cerebellar development, and to infer the path that they take from the ventricular epithelium through the deep cerebellar mass and nascent white matter into the cerebellar cortex (Fig. 3). The assertion of Maricich and Herrup (1999) that Pax2 positive interneuronal precursors form a neuronogenic population distinct from glial precursors was further substantiated by data which documented that dividing precursors in the deep cerebellar mass of 4-5 day old rat pups yield, upon further differentiation, descendants/

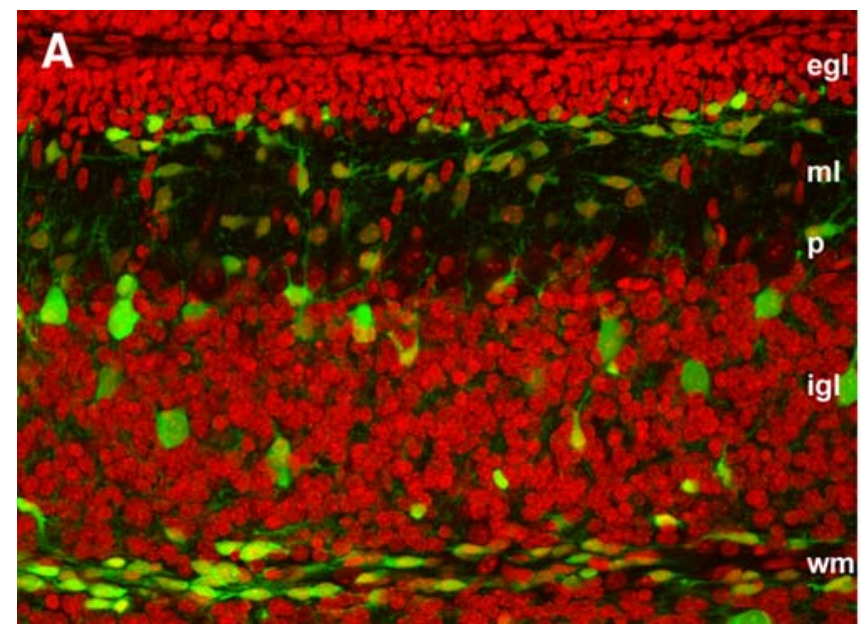

Fig. 3 a Location and morphology of Pax2-GFP-positive precursors of inhibitory interneurons (green) in the cerebellar cortex of an 8-day old mouse. Cell nuclei are counterstained in red. This image represents an optical section of $3.5 \mu \mathrm{m}$ thickness. b Same area as shown in panel $A$, but scanned to a tissue thickness of a total of $50 \mu \mathrm{m}$. Only the Pax2GFP signal is shown, and the position of positive cells along the $z$ axis (depth in the tissue block) is color-coded to give an impression of the clones which contained either cells with neuronal, astroglial, or oligodendroglial molecular signatures, but only very rarely mixed clones (Milosevic and Goldman 2002). Further in vitro studies by these authors (Milosevic and Goldman 2004) showed that mixed clones were obtained more frequently from proliferating precursors isolated from the cerebellar ventricular neuroepithelium, but only rarely from proliferating precursors isolated from the nascent white matter, implying at least some differentiation and lineage restriction of proliferating precursor cells migrating into the cerebellar anlage. Moreover, a quantitative analysis of Pax2-positive cells in the cerebellar anlage documented that only a minor fraction of these cells proliferate, and that indeed the numerical increase seen in Pax2-positive cerebellar cortical inhibitory interneurons in the early postnatal phase (assessed at postnatal days 0 and 3 in the mouse) can only be explained by proliferation of a Pax2-negative precursor population, and that Pax2-expression commences close to the time point that these cells go through their last mitosis (Weisheit et al. 2006). Together, these data suggest that Pax 2 should be perceived as a marker for early differentiating interneuronal precursors. Finally, it is only after they leave the ventricular epithelium that inhibitory interneuronal precursors become positive for Pax2 (Maricich and Herrup 1999); cf also Vilz et al. 2005 and Zordan et al. 2008) which again is in keeping with the observation of Herrup and associates (Maricich and Herrup 1999) that Pax2-positive cells, in contrast to ventricular epithelia, are strictly neuronogenic.

The notion that all GABAergic cerebellar interneurons share a common, molecularly defined lineage, as implied

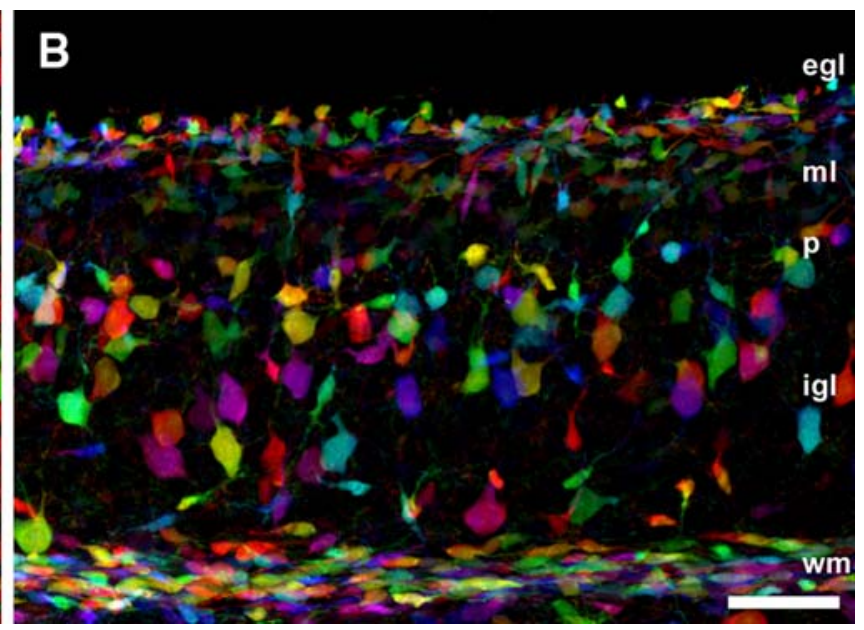

three-dimensional distribution of Pax2-positive interneuronal precursors. Note differences in cell shape, orientation and size in the nascent white matter $(\mathrm{wm})$, internal granule cell layer $(\mathrm{igl})$ and molecular layer. Note also the accumulation of Pax2-GFP-positive cells underneath the external granule cell layer $(e g l)$, which is not penetrated. $p$ Purkinje cell layer. Bar $50 \mu \mathrm{m}$ 
by these observations, is further supported by data that showed that genesis of these neurons, including that of GABAergic Purkinje cells, is critically dependent on Ptfla expression (Hoshino et al. 2005). In contrast, initial formation of granule cell precursors in the nascent external granule cell layer is not affected by mutating this gene actually, as elegantly shown by Pascual et al. (2007) lack of Ptf1a does not result in a failure of GABAergic precursors to form, or to their demise, but redirects these cells to acquire an excitatory, external granule cell layer fate. The fate and development of (purely) glycinergic cerebellar neurons (i.e., type 5 Golgi cells according to Simat et al. (2007) has not been analyzed in Ptf1a-null mice. In the retina, Ptf1a is also critical for the development of glycinergic cells (Nakhai et al. 2007). Therefore, it is tempting to speculate that Ptf1a is critical to development of all inhibitory neurons of the cerebellum.

In the forebrain, GABAergic interneuron diversity of the adult cortex is preceded by, and implemented through, spatial genetic patterning of the embryonic neuroepithelium (e.g., Fogarty et al. 2007). Analysis of proneural gene expression in the cerebellar anlage revealed that the early embryonic ventricular epithelium, from which Purkinje cells, and inhibitory cerebellar interneurons arise, is indeed heterogeneous, as documented by a patchy, and only partly overlapping pattern of expression of Mash1, Neurog1, and Neurog2 between embryonic day 10.75 and 13.5 (Zordan et al. 2008). Yet whether, and how these so defined populations relate to adult subsets of inhibitory cerebellar interneurons is not yet known.

Indeed, there is compelling evidence that inhibitory interneuronal precursor, rather than being irrevocably fated and determined within (or close to) the ventricular neuroepithelium, maintain a considerable level of developmental plasticity as they translocate through the nascent cerebellar anlage, and that their eventual fate and differentiation into, say molecular layer interneurons or Golgi cells is determined by local cues in their eventual territory of residency. This model is based on a large and systematic analysis of the development of genetically tagged cerebellar precursors following heterotopic and heterochronic transplantation into cerebella of embryonic, early postnatal, and adult hosts (Leto et al. 2006; see also Leto et al. 2008). Importantly, these studies also showed that the developmental potential of interneuronal precursors is not progressively restricted over the time course of cerebellar histogenesis. Thus, even precursors that are normally destined to form stellate cells (i.e., the type of inhibitory interneuron formed last during normal development) can give rise to, say, Golgi cells, or even deep nuclear inhibitory interneurons, which normally are formed and differentiate much earlier, when transplanted into the (internal) granule cell layer, the normal Golgi "residential area", or into the region of deep nuclei.
This protracted developmental plasticity, which persists well beyond the terminal mitosis of cerebellar inhibitory interneuronal precursors, clearly distinguishes them, say, from forebrain neurons. The developmental potential of forebrain cortical neuronal precursors becomes progressively restricted over time (Desai and McConnell 2000), and these cells are typically fated by signals received during a rather restricted time window around their last mitosis, within or close to the ventricular zone. Another key feature of cortical neuron development is that such fatedefining signals can only be realized by cycling cells, and indeed cell sensitivity toward such signals varies over the cell cycle (e.g., McConnell and Kaznowski 1991; Fukumitsu et al. 2006; Leone et al. 2008).

Yet there is also evidence suggesting that these seemingly so diverse time courses and strategies of neuronal fate determination might actually be subserved by the same, or closely related (molecular) mechanisms. A first hint came from in vitro studies that documented that development of cerebellar inhibitory interneuronal precursors, like that of granule cells, is indeed sensitive to extrinsic signals in a cell cycle dependent way (Baader et al. 1999). Moreover, it has been realized that migrating, Pax2-positive inhibitory interneuronal precursors in the cerebellar anlage maintain expression of the proliferation marker, Ki67, although they do not actually divide. Thus, in precursors of basket and stellate cells, Ki67 expression can be observed up to their arrival in the molecular layer (Weisheit et al. 2006). And finally, the above mentioned dependence of stellate cell development on cyclin D2 (Huard et al. 1999) needs to be reconsidered in this context. In the cerebellar anlage, cyclin D2 is expressed in the external granule cell layer and in what seem to be largely inhibitory interneuronal precursors transiting through the nascent white matter and forming layers of the cerebellum (cf Fig. 6a of Ciemerych et al. 2002; see also the cyclin D2 expression pattern at postnatal day 7 as documented in the BGEM [Magdaleno et al. 2006) and genepaint (Visel et al. 2004) databases]. Beyond its role in cell cycle progression, cyclin D2 can act to induce and/or maintain a non-proliferative state (Meyyappan et al. 1998); thus it is tempting to speculate whether sustained expression of cyclin D2 primarily restricts proliferative activity of translocating precursors of cerebellar inhibitory interneurons. Indeed, Huard et al. (1999) already suggested that the lack of stellate cells in cyclin D2-null mice may be explained by effects other than that on cell cycle progression.

In any case, the observation of cyclin D2 and Ki67 expression in migratory, non-dividing precursors of cerebellar inhibitory interneurons document that these cells persist in a state clearly distinct from full-blown $G_{0}$ phase. Thus, a model may be envisaged according to which the terminal fate and differentiation of cerebellar inhibitory interneurons, like that of many other central nervous 
neurons, is defined by cues acting during a phase related to their last mitosis. What distinguishes cerebellar inhibitory interneurons form, say, forebrain cortical projection neurons, is that this phase is apparently extended, as revealed by (and caused/implemented through?) their continued expression of cyclin D2 and Ki67. As a consequence, these cells are capable of integrating environmental developmental signals far off the immediate vicinity of their final mitosis, in areas they reach only after protracted translocation. The observation that mice null for the ErbB4 receptor have increased numbers of large granule cell layer inhibitory interneurons suggests a role for the ErbB4/neuregulin signaling pathway in this scenario (Tidcombe et al. 2003). Further, in vitro observations support the notion that such local cues include electrical activity and BDNF, which have been noted to regulate the expression of mGluR2 and parvalbumin, and also dendritic morphogenesis of cerebellar interneurons (Koscheck et al. 2003; Mertz et al. 2000). These data suggest that the interpretation of such signals, and specifically that of BDNF, might be critically modulated either by the electrical activity, or geometrical constraints, similar to those that migrating interneuronal precursors encounter in various parts of the cerebellar anlage they have to traverse, or where they eventually settle.

\section{Migration of cerebellar inhibitory interneurons and neuritogenesis}

A question that immediately follows, then, is: how is migration of cerebellar inhibitory interneuronal precursors regulated? Mathis et al. suggested a role for oligodendroytes and/or their precursors, based on the observation that transgenic ablation of these cells results in a severe disturbance of the migration and/or differentiation of cerebellar cortical inhibitory interneurons (Mathis et al. 2003). However, the thymidine kinase/FIAU system they used to eliminate oligodendritic cells is notorious for its ability to kill not only those cells primarily targeted, but also nearby cells. Indeed, this "bystander"-effect is currently actively exploited for the development of stem-cell based antitumor therapies (e.g., Uhl et al. 2005; Li et al. 2005). This effect is facilitated by gap-junctional coupling (Mesnil and Yamasaki 2000), which may be surmised to be active also in Pax2-positive precursors of cerebellar cortical inhibitory interneurons, that, like cerebellar oligodendrocytic cells, express connexins (Maxeiner et al. 2003; Kunzelmann et al. 1997). Thus, the physiological significance of the observations of Mathis et al. (2003) is currently hard to fathom.

A better and more in-depth understanding of the mechanisms that regulate the migration and appropriate distribution of cerebellar interneurons seems of prime importance, given that the final differentiation and function of these cells is eventually triggered in their area of residency (cf above; see Leto et al. 2006). Further, as there occurs but very little apoptosis, at least among basket and stellate neurons (Yamanaka et al. 2004), cell elimination seems of minor significance to assure numerical matching and appropriate spacing. Migrating interneuronal precursors are confronted with structurally quite different territories, including the nascent white matter, the internal granule cell layer, and, after becoming molecular layer interneurons, also the Purkinje and molecular layers. Conceptually, the issue of how proper navigation and settling is regulated may be broken down into several broad questions. E.g., what triggers interneuronal precursors migrating through the nascent white matter to leave this territory either at the base, or the apex of an emerging cerebellar folium? How is the decision to either stop in the nascent (internal) granule cell layer, or to proceed in to the molecular layer implemented in molecular terms? Do interneurons that have reached their final destination signal-back to their brethren still en route and thereby impinge on the latter's migrational behaviour, e.g., by modulation of Purkinje cell output which would then be sensed by migratory cells in the nascent white matter? Functional integration of both Golgi and basket/stellate cells (i.e., inhibiton of granule cells and Purkinje cells, respectively), which would be a prerequisite for such a scenario, has been documented, in the rat, at about postnatal days 10-12, (Shimono et al. 1976), i.e. at about midway during the formation of the molecular and granule cell layers. Once inhibitory interneurons have reached their laminar destination, how is their appropriate spacing achieved? And, related to this, how is the tiling of their dendrites, and the precise targeting of their axons realized? We have no real answers to the first three of these questions, but model systems to address these issues are now about to be developed (see, e.g., Hecker et al. 2008).

In contrast, recent results suggest at least some basic principles governing basket/stellate cell axon formation. Cerebellar Purkinje cells have been historically an outstanding example to study subcellular segregation of diverse afferents and their (mutual) regulation, including parallel and climbing fibers (e.g., Chen and Hillman 1982; Sotelo 1990; Cesa et al. 2007), both of which synapse onto discernible types of dendritic spines. Basket cells project to the Purkinje cell bodies and the axon initial hillock actually this is the very prerequisite to define a basket cell. Stellate cells in contrast, project to more distant dendritic shafts. This differential innervation by inhibitory interneurons is paralleled, and may indeed be realized through a gradient of cell adhesivity mediated by the subcellular distribution of neurofascin (Ango et al. 2004). A parsimonious explanation then would be that the decision to develop into a basket or stellate cell would eventually reflect the timing of when 
the axons of these cells actually invest Purkinje cells. Those that arrive early on can secure highly attractive (and adhesive) Purkinje cell territories around the axon hillock and cell body; axons which reach Purkinje cells later on have to settle for less adhesive distal dendritic shafts. As those molecular layer interneurons which arrive first in the molecular layer, and presumably also have a head-start to elaborate their axons, settle in the lower molecular layer (Miale and Sidman 1961; Altman and Bayer 1997), this would also explain the general conception that basket cells (preferentially) reside in the lower molecular layer. Cells that arrive later in the molecular layer and settle more superficially, and would find only more distal dendrites free to innervate. A twist to this story is added by the finding that developmental interaction between Purkinje cells and their afferent inhibitory neurons is mediated, or at least modulated, by Bergmann astroglial cells (Ango et al. 2008).

\section{More markers, more cells?}

Localization of an ever expanding panel of molecules within the cerebellar cortex may be expected to necessitate ongoing modification of the traditional classifications of cerebellar interneurons, but also to eventually facilitate our understanding of the development and function of these cells. An example in question is the novel neurochemical diversity of Golgi cells (Simat et al. 2007) sketched above. Meanwhile, histological and immunocytochemical analysis of the cerebellum has also suggested the potential existence of additional types of neurons. Thus, Crook et al. have described an apparently very rare, but rather large neuronal phenotype localized within the cerebellar white matter (Crook et al. 2007). These cat-301 positive cells are contacted (innervated) by GAD/calbindin D28 k-doubly immunoreactive collaterals (i.e., Purkinje cells). Their exact wiring is elusive, as is their function. Interestingly, an apparently very similar, if not identical cellular phenotype has also been observed in the cerebellum of several aquatic mammals, as reported by Addison already in 1931 (Addison 1931). Further, these cells are also reminiscent of the synarmotic cells described first by Landau (1927) and later by Braak (1974), who also argued that they might be a subset of Lugaro cells.

Staining of murine cerebella for Npas3 highlighted a group of cells positive for this basic HLH transcription factor, located within the granule cell layer, the numbers and distribution of which does not conform with any known cerebellar cell type (Erbel-Sieler et al. 2004). Npas3-null mice show a behavioral phenotype pointing to a cerebellar dysfunction (Brunskill et al. 2005). Still, the function and nature of these cells remains enigmatic.
Finally, staining of murine cerebella for NeuN highlighted a group of cells, located in the lower molecular layer, which so far have not been identified (Weyer and Schilling 2003). This study also showed that molecularly identified cerebellar cortical inhibitory interneurons do not stain for NeuN, just like Purkinje cells, and also unipolar brush cells. Among molecular markers discussed here, NeuN is the exception in that it is not genetically defined (see also Lind et al. 2004). For all other markers, the ability to eventually tag the cellular phenotypes expressing them vitally will not only allow to follow these cells during development, but also to identify them in vivo for physiological studies.

\section{Concluding remarks}

While the results summarized above leave little doubt that cerebellar inhibitory interneurons constitute a more diverse and complex complement of cells than traditional classifications acknowledge, these results also provide vantage points that should eventually allow us to arrive at an integrated view of how the cerebellar circuitry is formed and functions. Needless to say, this goal is still far off, and as is so often the case, novel results have also generated novel questions. Fortunately, recent progress has not only focused attention on cerebellar interneurons, but also provides important tools and approaches to follow up on these leads. Clearly, we would like to learn in much more detail how interneuronal precursors navigate the cerebellar anlage, and how they eventually become integrated in the cerebellar circuitry. Also, does the molecular diversity that has been uncovered, and that certainly will still be expanded, reflect the endpoint of a developmental process, or rather an aspect of functional plasticity? A closely related question, of both developmental and clinical interest, is whether there exists any relationship between inhibitory interneuronal lineages and cerebellar tumorigenesis. To date, the developmental origin of only a subgroup of medulloblastoma, the most common and devastating cerebellar malignant tumor, could be traced to the granule cell lineage (cf Pietsch et al. 2004; Gilbertson and Ellison 2008 for detailed discussions and primary references). It is therefore tempting to speculate whether other forms of medulloblastoma might be derived from cells that normally would form inhibitory cerebellar (inter) neurons. Currently, there is hardly any evidence to this end, but one has to consider that we still are rather ignorant with respect to molecular markers that might define the inhibitory interneuronal lineage. $\mathrm{Pax} 2$ is expressed in it only around its last mitosis (cf above; see also (Weisheit et al. 2006), and thus it may not be surprising that this relatively "late" marker was not found in medulloblastoma (Kozmik et al. 1995). 
Clearly, the realization that cerebellar circuitry comprises a more diverse set of cellular constituents than traditionally perceived has made it a more complex, but also a more interesting paradigm to analyze the mechanisms that bring about the formation and proper function of the central nervous system. While we are faced with the challenge yet to integrate these diverse cellular phenotypes into a coherent picture of how the cerebellum works, it may be hoped that the appreciation and clarification of this diversity will also provide an opportunity to overcome some of the roadblocks that still hamper progress towards a coherent view of cerebellar function.

Acknowledgments We thank various members of our labs for helpful discussions and suggestions. Work in our laboratories was supported by grants from the DAAD, NSF grant \#IBN-0138147 to J.O., the Compagnia di San Paolo (Neurotransplant Project, 2004.2019 2007.0660), and the Regione Piemonte (Proj. A14/05 and 865/2006).

Open Access This article is distributed under the terms of the Creative Commons Attribution Noncommercial License which permits any noncommercial use, distribution, and reproduction in any medium, provided the original author(s) and source are credited.

\section{References}

Addison WHF (1931) Unusual large nerve cells in the cerebellar cortex of several aquatic mammals. Anat Rec 48:7-72

Altman J, Bayer SA (1977) Time of origin and distribution of a new cell type in the rat cerebellar cortex. Exp Brain Res 29:265-274

Altman J, Bayer SA (1997) Development of the cerebellar system in relation to its evolution, structure, and functions. CRC Press, Boca Raton

Anelli R, Dunn ME, Mugnaini E (2000) Unipolar brush cells develop a set of characteristic features in primary cerebellar cultures. J Neurocytol 29:129-144

Anelli R, Mugnaini E (2001) Enrichment of unipolar brush cell-like neurons in primary rat cerebellar cultures. Anat Embryol (Berlin) 203:283-292

Ango F, Di CG, Higashiyama H, Bennett V, Wu P, Huang ZJ (2004) Ankyrin-based subcellular gradient of neurofascin, an immunoglobulin family protein, directs GABAergic innervation at purkinje axon initial segment. Cell 119:257-272

Ango F, Wu C, van der Want JJ, Wu P, Schachner M, Huang ZJ (2008) Bergmann glia and the recognition molecule CHL1 organize GABAergic axons and direct innervation of Purkinje cell dendrites. PLoS Biol 6:e103

Apps R, Garwicz M (2005) Anatomical and physiological foundations of cerebellar information processing. Nat Rev Neurosci 6:297-311

Baader SL, Bergmann M, Mertz K, Fox PA, Gerdes J, Oberdick J, Schilling K (1999) The differentiation of cerebellar interneurons is independent of their mitotic history. Neuroscience 90:1243-1254

Berthie B, Axelrad H (1994) Granular layer collaterals of the unipolar brush cell axon display rosette-like excrescences. A Golgi study in the rat cerebellar cortex. Neurosci Lett 167:161-165

Boyden ES, Katoh A, Raymond JL (2004) Cerebellum-dependent learning: the role of multiple plasticity mechanisms. Annu Rev Neurosci. 27:581-609

Braak H (1974) On the intermediate cells of lugaro within the cerebellar cortex of man. A pigmentarchitectonic study. Cell Tissue Res 149:399-411
Brockhaus J, Dressel D, Herold S, Deitmer JW (2004) Purinergic modulation of synaptic input to Purkinje neurons in rat cerebellar brain slices. Eur J NeuroSci 19:2221-2230

Brunskill EW, Ehrman LA, Williams MT, Klanke J, Hammer D, Schaefer TL, Sah R, Dorn GW, Potter SS, Vorhees CV (2005) Abnormal neurodevelopment, neurosignaling and behaviour in Npas3-deficient mice. Eur J NeuroSci 22:1265-1276

Caviness VS Jr, Rakic P (1976) Mechanisms of cortical development: a view from mutant mice. Annu Rev Neurosci 1:297-326

Cesa R, Scelfo B, Strata P (2007) Activity-dependent presynaptic and postsynaptic structural plasticity in the mature cerebellum. J Neurosci 27:4603-4611

Chaudhry FA, Reimer RJ, Bellocchio EE, Danbolt NC, Osen KK, Edwards RH, Storm-Mathisen J (1998) The vesicular GABA transporter, VGAT, localizes to synaptic vesicles in sets of glycinergic as well as GABAergic neurons. J Neurosci 18:9733-9750

Chen S, Hillman DE (1982) Plasticity of the parallel fiber-Purkinje cell synapse by spine takeover and new synapse formation in the adult rat. Brain Res 240:205-220

Chiu CS, Jensen K, Sokolova I, Wang D, Li M, Deshpande P, Davidson N, Mody I, Quick MW, Quake SR, Lester HA (2002) Number, density, and surface/cytoplasmic distribution of GABA transporters at presynaptic structures of knock-in mice carrying GABA transporter subtype 1-green fluorescent protein fusions. J Neurosci 22:10251-10266

Ciemerych MA, Kenney AM, Sicinska E, Kalaszczynska I, Bronson RT, Rowitch DH, Gardner H, Sicinski P (2002) Development of mice expressing a single D-type cyclin. Genes Dev 16:3277-3289

Crook J, Hendrickson A, Robinson FR (2006) Co-localization of glycine and gaba immunoreactivity in interneurons in Macaca monkey cerebellar cortex. Neuroscience 141:1951-1959

Crook JD, Hendrickson A, Erickson A, Possin D, Robinson FR (2007) Purkinje cell axon collaterals terminate on Cat-301+ neurons in Macaca monkey cerebellum. Neuroscience 149:834-844

Dean I, Robertson SJ, Edwards FA (2003) Serotonin drives a novel GABAergic synaptic current recorded in rat cerebellar purkinje cells: a Lugaro cell to Purkinje cell synapse. J Neurosci 23:4457-4469

Desai AR, McConnell SK (2000) Progressive restriction in fate potential by neural progenitors during cerebral cortical Development. Development 127:2863-2872

Dieudonne S (1995) Glycinergic synaptic currents in Golgi cells of the rat cerebellum. Proc Natl Acad Sci USA 92:1441-1445

Dieudonne S, Dumoulin A (2000) Serotonin-driven long-range inhibitory connections in the cerebellar cortex. J Neurosci 20:1837-1848

Dino MR, Schuerger RJ, Liu Y, Slater NT, Mugnaini E (2000) Unipolar brush cell: a potential feedforward excitatory interneuron of the cerebellum. Neuroscience 98:625-636

Dugue GP, Dumoulin A, Triller A, Dieudonne S (2005) Target-dependent use of coreleased inhibitory transmitters at central synapses. J Neurosci 25:6490-6498

Dumoulin A, Triller A, Dieudonne S (2001) IPSC kinetics at identified GABAergic and mixed GABAergic and glycinergic synapses onto cerebellar Golgi cells. J Neurosci 21:6045-6057

Englund C, Kowalczyk T, Daza RA, Dagan A, Lau C, Rose MF, Hevner RF (2006) Unipolar brush cells of the cerebellum are produced in the rhombic lip and migrate through developing white matter. J Neurosci 26:9184-9195

Erbel-Sieler C, Dudley C, Zhou Y, Wu X, Estill SJ, Han T, Diaz-Arrastia R, Brunskill EW, Potter SS, McKnight SL (2004) Behavioral and regulatory abnormalities in mice deficient in the NPAS1 and NPAS3 transcription factors. Proc Natl Acad Sci USA 101:13648-13653

Farhan H, Reiterer V, Kriz A, Hauri HP, Pavelka M, Sitte HH, Freissmuth M (2008) Signal-dependent export of GABA transporter 1 from the ER-Golgi intermediate compartment is specified by a Cterminal motif. J Cell Sci 121:753-761 
Flace P, Benagiano V, Lorusso L, Girolamo F, Rizzi A, Virgintino D, Roncali L, Ambrosi G (2004) Glutamic acid decarboxylase immunoreactive large neuron types in the granular layer of the human cerebellar cortex. Anat Embryol (Berlin) 208:55-64

Floris A, Dino M, Jacobowitz DM, Mugnaini E (1994) The unipolar brush cells of the rat cerebellar cortex and cochlear nucleus are calretinin-positive: a study by light and electron microscopic immunocytochemistry. Anat Embryol (Berlin) 189:495-520

Fogarty M, Grist M, Gelman D, Marin O, Pachnis V, Kessaris N (2007) Spatial genetic patterning of the embryonic neuroepithelium generates GABAergic interneuron diversity in the adult cortex. J Neurosci 27:10935-10946

Fox CA, Hillman DE, Siegesmund KA, Dutta CR (1967) The primate cerebellar cortex: a Golgi and electron microscopic study. Prog Brain Res 25:174-225

Fremeau RT Jr, Kam K, Qureshi T, Johnson J, Copenhagen DR, Storm-Mathisen J, Chaudhry FA, Nicoll RA, Edwards RH (2004) Vesicular glutamate transporters 1 and 2 target to functionally distinct synaptic release sites. Science 304:1815-1819

Fujita S (1967) Quantitative analysis of cell proliferation and differentiation in the cortex of the postnatal mouse cerebellum. J Cell Biol $32: 277-287$

Fukumitsu H, Ohtsuka M, Murai R, Nakamura H, Itoh K, Furukawa S (2006) Brain-derived neurotrophic factor participates in determination of neuronal laminar fate in the developing mouse cerebral cortex. J Neurosci 26:13218-13230

Geurts FJ, De Schutter E, Dieudonne S (2003) Unraveling the cerebellar cortex: cytology and cellular physiology of large-sized interneurons in the granular layer. Cerebellum 2:290-299

Geurts FJ, Timmermans J, Shigemoto R, De Schutter E (2001) Morphological and neurochemical differentiation of large granular layer interneurons in the adult rat cerebellum. Neuroscience 104:499-512

Gilbertson RJ, Ellison DW (2008) The origins of medulloblastoma subtypes. Annu Rev Pathol 3:341-365

Glickstein SB, Moore H, Slowinska B, Racchumi J, Suh M, Chuhma N, Ross ME (2007) Selective cortical interneuron and GABA deficits in cyclin D2-null mice. Development 134:4083-4093

Gliem M, Weisheit G, Mertz KD, Endl E, Oberdick J, Schilling K (2006) Expression of classical cadherins in the cerebellar anlage: Quantitative and functional aspects. Mol Cell Neurosci 33:447-458

Goldowitz D, Hamre K (1998) The cells and molecules that make a cerebellum. TINS 21:375-382

Golgi C (1903) Sulla fina anatomia del cervelletto umano. Lecture, Istituto Lombardo di Sci. e Lett. 8 January 1874. In: Opera Omnia, Istologia normale, chap. V, vol I. Ulrico Hoepli, Milano, pp 99-111

Hallonet MER, Le Douarin NM (1993) Tracing neuroepithelial cells of the mesencephalic and metencephalic alar plates during cerebellar ontogeny in quil-chick chimaeras. Eur J Neurosci 5:1145-1155

Harris J, Moreno S, Shaw G, Mugnaini E (1993) Unusual neurofilament composition in cerebellar unipolar brush neurons. J Neurocytol 22:1039-1059

Hecker D, Kappler J, Glassmann A, Schilling K, Alt W (2008) Image analysis of time-lapse movies-A precision control guided approach to correct motion artefacts. J Neurosci Methods 172:67-73

Hoshino M, Nakamura S, Mori K, Kawauchi T, Terao M, Nishimura YV, Fukuda A, Fuse T, Matsuo N, Sone M, Watanabe M, Bito H, Terashima T, Wright CV, Kawaguchi Y, Nakao K, Nabeshima Y (2005) Ptf1a, a bHLH transcriptional gene, defines GABAergic neuronal fates in cerebellum. Neuron 47:201-213

Huard JMT, Forster CC, Carter ML, Sicinski P, Ross ME (1999) Cerebellar histogenesis is disturbed in mice lacking cyclin D2. Development 126:1927-1935

Ilijic E, Guidotti A, Mugnaini E (2005) Moving up or moving down? Malpositioned cerebellar unipolar brush cells in reeler mouse. Neuroscience 136:633-647
Ito M (2008) Control of mental activities by internal models in the cerebellum. Nat Rev Neurosci 9:304-313

Jaarsma D, Wenthold RJ, Mugnaini E (1995) Glutamate receptor subunits at mossy fiber-unipolar brush cell synapses: light and electron microscopic immunocytochemical study in cerebellar cortex of rat and cat. J Comp Neurol 357:145-160

Koscheck T, Weyer A, Schilling RL, Schilling K (2003) Morphological development and neurochemical differentiation of cerebellar inhibitory interneurons in microexplant cultures. Neuroscience 116:973-984

Kozmik Z, Sure U, Ruedi D, Busslinger M, Aguzzi A (1995) Deregulated expression of PAX5 in medulloblastoma. Proc Natl Acad Sci USA 92:5709-5713

Kunzelmann P, Blumcke I, Traub O, Dermietzel R, Willecke K (1997) Coexpression of connexin 45 and -32 in oligodendrocytes of rat brain. J Neurocytol 26:17-22

Laine J, Axelrad H (1994) The candelabrum cell: a new interneuron in the cerebellar cortex. J Comp Neurol 339:159-173

Laine J, Axelrad H (1996) Morphology of the Golgi-impregnated Lugaro cell in the rat cerebellar cortex: a reappraisal with a description of its axon. J Comp Neurol 375:618-640

Laine J, Axelrad H (1998) Lugaro cells target basket and stellate cells in the cereballer cortex. NeuroReport 13:2399-2403

Laine J, Axelrad H (2002) Extending the cerebellar Lugaro cell class. Neuroscience 115:363-374

Landau E (1927) Beitrag zur Kenntnis der Körnerschicht des Kleinhirns. Anat Anz 62:391-398

Lander C, Kind P, Maleski M, Hockfield S (1997) A family of activitydependent neuronal cell-surface chondroitin sulfate proteoglycans in cat visual cortex. J Neurosci 17:1928-1939

Lander C, Zhang H, Hockfield S (1998) Neurons produce a neuronal cell surface-associated chondroitin sulfate proteoglycan. J Neurosci 18:174-183

Lein ES, Hawrylycz MJ, Ao N, Ayres M, Bensinger A, Bernard A et al (2007) Genome-wide atlas of gene expression in the adult mouse brain. Nature 445:168-176

Leone DP, Srinivasan K, Chen B, Alcamo E, McConnell SK (2008) The determination of projection neuron identity in the developing cerebral cortex. Curr Opin Neurobiol 18:28-35

Leto K, Bartolini A, Rossi F (2008) Development of cerebellar GABAergic interneurons: origin and shaping of the minibrain cocal connections. The Cerebellum (in press)

Leto K, Carletti B, Williams IM, Magrassi L, Rossi F (2006) Different types of cerebellar GABAergic interneurons originate from a common pool of multipotent progenitor cells. J Neurosci 26:11682-11694

Li J, Lao Z, Joyner A (2002) Changing requirements for gbx2 in development of the cerebellum and maintenance of the mid/hindbrain organizer. Neuron 36:31-43

Li S, Tokuyama T, Yamamoto J, Koide M, Yokota N, Namba H (2005) Potent bystander effect in suicide gene therapy using neural stem cells transduced with herpes simplex virus thymidine kinase gene. Oncology 69:503-508

Lind D, Franken S, Kappler J, Jankowski J, Schilling K (2004) Characterization of the neuronal marker NeuN as a multiply phosphorylated antigen with discrete subcellular localization. J Neurosci Res 79:295-302

Lugaro E (1894) Sulle connessioni tra gli elementi nervosi della corteccia cerebellare con considerazioni generali sul significato fisiologico dei rapporti tra gli elementi nervosi. Riv Sper Fren Med Leg 20:297-331

Magdaleno S, Jensen P, Brumwell CL, Seal A, Lehman K, Asbury A, Cheung T, Cornelius T, Batten DM, Eden C, Norland SM, Rice DS, Dosooye N, Shakya S, Mehta P, Curran T (2006) BGEM: An In Situ Hybridization Database of Gene Expression in the Embryonic and Adult Mouse Nervous System. PLoS Biol 4:e86 
Maricich SM, Herrup K (1999) Pax-2 expression defines a subset of GABAergic interneurons and their precursors in the developing murine cerebellum. J Neurobiol 41:281-294

Martinez-Maza R, Poyatos I, Lopez-Corcuera B, Unez N, Gimenez C, Zafra F, Aragon C (2001) The role of N-glycosylation in transport to the plasma membrane and sorting of the neuronal glycine transporter GLYT2. J Biol Chem 276:2168-2173

Mathis C, Collin L, Borrelli E (2003) Oligodendrocyte ablation impairs cerebellum development. Development 130:4709-4718

Mathis L, Bonnerot C, Puelles L, Nicolas JF (1997) Retrospective clonal analysis of the cerebellum using genetic laacZ/lacZ mouse mosaics. Development 124:4089-4104

Matthews RT, Kelly GM, Zerillo CA, Gray G, Tiemeyer M, Hockfield S (2002) Aggrecan glycoforms contribute to the molecular heterogeneity of perineuronal nets. J Neurosci 22:7536-7547

Maxeiner S, Kruger O, Schilling K, Traub O, Urschel S, Willecke K (2003) Spatiotemporal transcription of connexin45 during brain development results in neuronal expression in adult mice. Neuroscience 119:689-700

McConnell SK, Kaznowski CE (1991) Cell cycle dependence of laminar determination in developing neocortex. Science 254:282285

Mertz K, Koscheck T, Schilling K (2000) Brain derived neuronotrophic factor modulates dendritic morphology of cerebellar basket and stellate cells. Neuroscience 97:303-310

Mesnil M, Yamasaki H (2000) Bystander effect in herpes simplex virus-thymidine kinase/ganciclovir cancer gene therapy: role of gap-junctional intercellular communication. Cancer Res 60:3989-3999

Meyyappan M, Wong H, Hull C, Riabowol KT (1998) Increased expression of cyclin D2 during multiple states of growth arrest in primary and established cells. Mol Cell Biol 18:3163-3172

Miale IR, Sidman RL (1961) An autoradiographic analysis of histogenesis in the mouse cerebellum. Exp Neurol 4:277-296

Millen KJ, Gleeson JG (2008) Cerebellar development and disease. Curr Opin Neurobiol 18:12-19

Milosevic A, Goldman JE (2002) Progenitors in the postnatal cerebellar white matter are antigenically heterogeneous. J Comp Neurol 452:192-203

Milosevic A, Goldman JE (2004) Potential of progenitors from postnatal cerebellar neuroepithelium and white matter: lineage specified vs.multipotent fate. Mol Cell Neurosci 26:342-353

Morin F, Dino MR, Mugnaini E (2001) Postnatal differentiation of unipolar brush cells and mossy fiber-unipolar brush cell synapses in rat cerebellum. Neuroscience 104:1127-1139

Mugnaini E (1972) The histology and cytology of the cerebellar cortex. In: Larsell O, Jansen J (eds) The comparative histology of the cerebellum. The humal cerbellum, cerebellar connections and cerebellar cortex. University of Minnesota Press, Minneapolis, pp 201-264

Mugnaini E, Dino MR, Jaarsma D (1997) The unipolar brush cells of the mammalian cerebellum and cochlear nucleus: cytology and microcircuitry. Prog Brain Res 114:131-150

Mugnaini E, Floris A (1994) The unipolar brush cell: a neglected neuron of the mammalian cerebellar cortex. J Comp Neurol 339:174-180

Mugnaini E, Floris A, Wright-Goss M (1994) Extraordinary synapses of the unipolar brush cell: An electron microscopic study in the rat cerebellum. Synapse 16:284-311

Muth TR, Ahn J, Caplan MJ (1998) Identification of sorting determinants in the C-terminal cytoplasmic tails of the gamma-aminobutyric acid transporters GAT-2 and GAT-3. J Biol Chem 273:25616-25627

Nakhai H, Sel S, Favor J, Mendoza-Torres L, Paulsen F, Duncker GI, Schmid RM (2007) Ptfla is essential for the differentiation of GABAergic and glycinergic amacrine cells and horizontal cells in the mouse retina. Development 134:1151-1160
Napieralski JA, Eisenman LM (1993) Developmental analysis of the external granule cell layer in the meander tail mutant mouse: do cerebellar microneurons have independent progenitors? Dev Dyn 197:244-254

Nunzi MG, Birnstiel S, Bhattacharyya BJ, Slater NT, Mugnaini E (2001) Unipolar brush cells form a glutamatergic projection system within the mouse cerebellar cortex. J Comp Neurol 434:329341

Nunzi MG, Russo M, Mugnaini E (2003) Vesicular glutamate transporters VGLUT1 and VGLUT2 define two subsets of unipolar brush cells in organotypic cultures of mouse vestibulocerebellum. Neuroscience 122:359-371

Nunzi MG, Shigemoto R, Mugnaini E (2002) Differential expression of calretinin and metabotropic glutamate receptor mGluR1alpha defines subsets of unipolar brush cells in mouse cerebellum. J Comp Neurol 451:189-199

Oberdick J, Baader SL, Schilling K (1998) From zebra stripes to postal zones: deciphering patterns of gene expression in the cerebellum. TINS 21:383-391

Ottersen OP, Davanger S, Storm-Mathisen J (1987) Glycine-like immunoreactivity in the cerebellum of rat and Senegalese baboon, Papio papio: a comparison with the distribution of GABAlike immunoreactivity and with $[3 \mathrm{H}]$ glycine and $[3 \mathrm{H}] \mathrm{GABA}$ uptake. Exp Brain Res 66:211-221

Palay SL, Chan-Palay V (1974) Cerebellar cortex. Cytology and organization. Springer-Verlag, Berlin

Pascual M, Abasolo I, Mingorance-Le Meur A, Martinez A, Del Rio JA, Wright CV, Real FX, Soriano E (2007) Cerebellar GABAergic progenitors adopt an external granule cell-like phenotype in the absence of Ptfla transcription factor expression. Proc Natl Acad Sci USA 104:5193-5198

Pietsch T, Taylor MD, Rutka JT (2004) Molecular pathogenesis of childhood brain tumors. J Neurooncol 70:203-215

Porrill J, Dean P, Stone JV (2004) Recurrent cerebellar architecture solves the motor-error problem. Proc Biol Sci 271:789-796

Ramon y Cajal S (1899) Textura del Sistema Nervioso del Hombre y de los Vertebrados. Moya, Madrid

Ramon y Cajal S (1909) Histologie du système nerveux de l'homme et des vertébrés. II. A. Maloine, Paris

Rong Y, Wang T, Morgan JI (2004) Identification of candidate Purkinje cell-specific markers by gene expression profiling in wildtype and pcd(3 J) mice. Mol Brain Res 132:128-145

Rossi DJ, Alford S, Mugnaini E, Slater NT (1995) Properties of transmission at a giant glutamatergic synapse in cerebellum: the mossy figer-unipolar brush cell synapse. J Neurophysiol 74:24-42

Sahin M, Hockfield S (1990) Molecular identification of the Lugaro cell in the cat cerebellar cortex. J Comp Neurol 301:575-584

Saitow F, Murakoshi T, Suzuki H, Konishi S (2005) Metabotropic P2Y purinoceptor-mediated presynaptic and postsynaptic enhancement of cerebellar GABAergic transmission. J Neurosci 25:2108_ 2116

Schuske K, Jorgensen EM (2004) Vesicular glutamate transportershooting blanks. Science 304:1750-1752

Sekerkova G, Ilijic E, Mugnaini E (2004) Time of origin of unipolar brush cells in the rat cerebellum as observed by prenatal bromodeoxyuridine labeling. Neuroscience 127:845-858

Shimono T, Nosaka S, Sasaki K (1976) Electrophysiological study on the postnatal development of neuronal mechanisms in the rat cerebellar cortex. Brain Res 108:279-294

Simat M, Parpan F, Fritschy JM (2007) Heterogeneity of glycinergic and gabaergic interneurons in the granule cell layer of mouse cerebellum. J Comp Neurol 500:71-83

Sotelo C (1990) Cerebellar synaptogenesis: what we can learn from mutant mice. J Exp Biol 153:225-249

Sotelo C (2004) Cellular and genetic regulation of the development of the cerebellar system. Prog Neurobiol 72:295-339 
Sultan F, Bower JM (1998) Quantitative Golgi study of the rat cerebellar molecular layer interneurons using principal component analysis. J Comp Neurol 393:353-373

Takacs J, Borostyankoi ZA, Veisenberger E, Vastagh C, Vig J, Gorcs TJ, Hamori J (2000) Postnatal development of unipolar brush cells in the cerebellar cortex of cat. J Neurosci Res 61:107-115

Tanaka I, Ezure K (2004) Overall distribution of GLYT2 mRNA-containing versus GAD67 mRNA-containing neurons and colocalization of both mRNAs in midbrain, pons, and cerebellum in rats. Neurosci Res 49:165-178

Tidcombe H, Jackson-Fisher A, Mathers K, Stern DF, Gassmann M, Golding JP (2003) Neural and mammary gland defects in ErbB4 knockout mice genetically rescued from embryonic lethality. Proc Natl Acad Sci USA 100:8281-8286

Triller A, Cluzeaud F, Korn H (1987) Gamma-aminobutyric acid-containing terminals can be apposed to glycine receptors at central synapses. J Cell Biol 104:947-956

Uhl M, Weiler M, Wick W, Jacobs AH, Weller M, Herrlinger U (2005) Migratory neural stem cells for improved thymidine kinase-based gene therapy of malignant gliomas. Biochem Biophys Res Commun 328:125-129

Vig J, Goldowitz D, Steindler DA, Eisenman LM (2005a) Compartmentation of the reeler cerebellum: Segregation and overlap of spinocerebellar and secondary vestibulocerebellar fibers and their target cells. Neuroscience 130:735-744

Vig J, Takacs J, Abraham H, Kovacs GG, Hamori J (2005b) Calretininimmunoreactive unipolar brush cells in the developing human cerebellum. Int J Dev Neurosci 23:723-729

Vilz TO, Moepps B, Engele J, Molly S, Littman DR, Schilling K (2005) The SDF-1/CXCR4 pathway and the development of the cerebellar system. Eur J NeuroSci 22:1831-1839
Visel A, Thaller C, Eichele G (2004) GenePaint.org: an atlas of gene expression patterns in the mouse embryo. Nucleic Acids Res 32:D552-D556

Voogd J, Glickstein M (1998) The anatomy of the cerebellum. TINS $21: 370-375$

Weisheit G, Gliem M, Endl E, Pfeffer PL, Busslinger M, Schilling K (2006) Postnatal development of the murine cerebellar cortex: formation and early dispersal of basket, stellate and Golgi neurons. Eur J NeuroSci 24:466-478

Weyer A, Schilling K (2003) Developmental and cell type-specific expression of the neuronal marker NeuN in the murine cerebellum. J Neurosci Res 73:400-409

Wojcik SM, Katsurabayashi S, Guillemin I, Friauf E, Rosenmund C, Brose N, Rhee JS (2006) A shared vesicular carrier allows synaptic corelease of GABA and glycine. Neuron 50:575-587

Xiang Z, Burnstock G (2005) Changes in expression of P2X purinoceptors in rat cerebellum during postnatal development. Dev Brain Res 156:147-157

Yamanaka H, Yanagawa Y, Obata K (2004) Development of stellate and basket cells and their apoptosis in mouse cerebellar cortex. Neurosci Res 50:13-22

Zervas M, Millet S, Ahn S, Joyner AL (2004) Cell behaviors and genetic lineages of the mesencephalon and rhombomere 1 . Neuron 43:345-357

Zhang L, Goldman JE (1996a) Developmental fates and migratory pathways of dividing progenitors in the postnatal rat cerebellum. J Comp Neurol 370:536-550

Zhang L, Goldman JE (1996b) Generation of cerebellar interneurons from dividing progenitors in white matter. Neuron 16:47-54

Zordan P, Croci L, Hawkes R, Consalez GG (2008) Comparative analysis of proneural gene expression in the embryonic cerebellum. Dev Dyn 237:1726-1735 